overnight, before either returning on his own accord or being brought back by the police.

Clinically he showed mild signs of organic dementia and was at times auditorily hallucinated and aggressive without provocation, e.g. knocking a cigarette out of a woman patient's hand. It was consequently decided to transfer him to the semi-closed male ward. Here, unfortunately, his habit of rummaging in other patients' lockers, and his confusion, upset some of the more aggressive patients and for his own safety transfer back to the admission ward became necessary and thence, when a bed became available, to a long-term male ward.

He had been seen by a consultant neurologist who commented that it had been some 20 years since he had seen a case of GPI. He found that the patient's pupils were small and irregular but just reacted to light and accommodation. His speech was markedly slurred and dysarthric, but no other abnormal CNS signs were elicited. Although he had already had two separate fortnights of Benzyl Penicillin b.d. following which had had improved markedly, it was felt that two further prolonged courses of Benzathine Penicillin would be appropriate in order to be certain of achieving continuous treponemicidal serum levels of penicillin. He was accordingly given Benzathine Penicillin 1.2 mega units every four days for 28 days; this was repeated after a month's interval.

Apart from the anti-syphilitic treatment described, psychotropic medication was initially mainly trifluoperazine with depixol $100 \mathrm{mg}$ IM three-weekly during a mildly paranoid phase, and amitriptyline when depressed. Lumbar puncture at this stage suggested cure of the treponemal infection with cells and protein having returned to normal (WBC $1 \times 10^{\circ} / 1$, Protein $0.35 \mathrm{~g} / \mathrm{l}$ ), although the VDPL was still positive at 1.8 (reference laboratory). Despite apparent cure of his infection, clinical deterioration has occurred-a well recognized problem. The nature of any possible progressive cerebral pathology is unknown.

From the psychiatric point of view the prognosis will presumably be that of a slowly progressive organic dementia. It seems unlikely that the florid grandiose delusions will recur, although the auditory hallucinations will probably do so.

\title{
An Historical Vignette: Surrealism and Anti-Psychiatry
}

This open letter/manifesto to medical directors of lunatic asylums appeared 60 years ago in La Révolution Surréaliste (Vol 1, No 3, p. 29, April 15, 1925). The editors, Pierre Naville and Benjamin Péret, later became founding members of the IVth (Trotskyist) International. It is likely that the main author was the leader of the French Surrealist group, Andre Breton. [Translated from French by Dr Petr Skrabanek and Dr Richard Walsh.]

\section{SIRS}

Law and custom grant you the right to measure the mind. It is with your understanding that you exercise this sovereign and fearsome jurisdiction. We have to laugh. The gullibility of civilized nations, of scholars, and of rulers bedecks psychiatry with god-knows-what supernatural illuminations. The trial of your profession is decided in advance. We do not intend to discuss here the worth of your science nor the dubious existence of mental diseases. But for a hundred pretentious pathogeneses, in which the confusion of matter and mind is unleashed, for a hundred classifications of which the most vague are yet the only usable ones, how many highminded attempts are made to come near to the cerebral world in which your prisoners live? How many of you, for example, are there for whom the dream of the schizophrenic, the images to which he is a prey, are anything but a word-salad?

It does not surprise us to find you unequal to a task for which only few are predestined. But we rise up against the right accorded to some men, limited or not, to sanction their investigations in the realm of the mind by perpetual

\section{imprisonment.}

And what imprisonment! It is known-but not widely enough-that the asylums far from being asylums are dreadful gaols, where the inmates provide free and convenient labour, and where ill-treatment is the rule - this you tolerate. The lunatic asylum, under the camouflage of science and justice, is comparable to the barracks, the prison, the penitentiary.

We do not wish to raise here the question of arbitrary internments, to save you the trouble of facile denials. We declare that a large number of your lodgers, perfectly mad according to the official definition, are no less arbitrarily interned. We do not accept that anyone may hinder the free blossoming of a person in delirium, something which is as legitimate and as logical as any other sequence of ideas or of human acts. The repression of antisocial reactions is as illusory as it is unacceptable in principle. All individual acts are antisocial. The madmen are the individual victims par excellence of social dictatorship; in the name of that individuality which is the mark of man, we demand that these convicts of sensitivity be set free-since it is not in the power of law to imprison all men who think and act.

Without emphasizing the utterly brilliant nature of what is manifest in certain madmen, as far as we are to understand it, we declare the absolute legitimacy of their concept of reality and of all the acts which derive from it.

Would you kindly remember this tomorrow morning at the ward-round when you try to converse, without the necessary vocabulary, with these men over whom-be it known to you-you have no superiority but that of force. 